\title{
Testing Evidence for Local Metalworking at Tell es-Sa'idiyeh, Jordan
}

\author{
Maria Laura Mascelloni \\ Università degli Studi dell'Aquila, Florence, Tuscany, Italy \\ Email: marialaura.mascelloni@hotmail.com
}

How to cite this paper: Mascelloni, M. L. (2020). Testing Evidence for Local Metalworking at Tell es-Sa'idiyeh, Jordan. $A d$ vances in Historical Studies, 9, 211-228. https://doi.org/10.4236/ahs.2020.94018

Received: June 11, 2020

Accepted: November 27, 2020

Published: November 30, 2020

Copyright $\odot 2020$ by author(s) and Scientific Research Publishing Inc. This work is licensed under the Creative Commons Attribution International License (CC BY 4.0).

http://creativecommons.org/licenses/by/4.0/

\section{(c) (i) Open Access}

\begin{abstract}
The study reports on the identification of chemical composition of samples, of natural and artificial origin, in order to investigate the technology involved and the contest of production of metals, slag and vitrified materials from the Jordanian site of Tell es-Sa'idiyeh. The site is situated in the east central Jordan Valley, $1.8 \mathrm{~km}$ east of the River Jordan, on the south side of the Wadi Kufrinjeh. The settlement is placed on two mounds: the Upper Tell, to the middle east of the site, lies $14 \mathrm{~m}$ above the plain level and covers an area of about $10,000 \mathrm{sq} \cdot \mathrm{m}$; and the Low Tell, approximately 90 by $40 \mathrm{~m}$ to the west, is about $20 \mathrm{~m}$ lower than the upper mound. The surrounding land may be considered some of the most fertile agricultural terrains in the country and the site occupies a key strategic position, dominating the crossroads of two major trade routes.
\end{abstract}

\section{Keywords}

Jordan, Archaeology, Archaeometry, Archaeometallurgy, Metalworking, Metals, Slags, Faiance, Vitrified Material

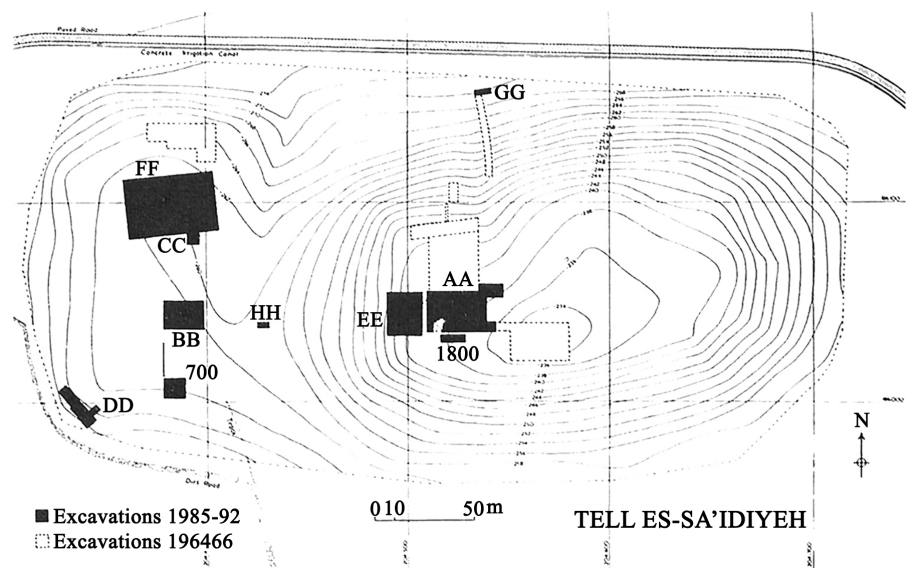




\section{Introduction}

Specifically selected for this research, an assemblage of metal, slag and vitrified materials from the Jordanian site of Tell es-Sa'idiyeh was delivered to me by Jonathan Tubb and Thilo Rehren in order to identify origin and composition of the different items, and eventually technologies involved in their production ${ }^{1}$. The twenty-two bags of samples come from different areas of the site and, chronologically, belong to very different ages ranging from the Early Bronze Age to the Hellenistic period (Table 1).

Levant Prehistory is one told, for the most part, through the material remains and the reconstruction of surrounding landscapes of the earliest evidence of hut settlements. Rarely, sites document burial or artistic evidence.

Also, metal finds are very rare in Jordan and occur only in Late Chalcolithic assemblages. Copper production in general, and especially the production of arsenic/antimony alloy objects, in Jordan would seem to be confined to the latest phases of the Beersheban Chalcolithic (Joffe and Dessel, 1995). If the end of the significant sequence at Ghassul occurred as a regional phenomenon, then many southern sites may have followed the same sharp decline or have ceased to be occupied by that time (Bourke, 1998, 1999). This could mean that the metal industry in Jordan may have been involved in a more regional decline in a still outgoing phase. On the other hand, recent excavations at Ghassul have recovered a number of pale brown, faience disk beads that represent one of the rare faience inventories reported from Late Chalcolithic contexts (Bourke et al., 1995: p. 5253). According to Peltenburg, faience beads may well derive from Egypt (Peltenburg, 1987: p. 1112; 1995: p. 3637), but in a more recent analysis, Bourke suggests that "a local production associated with small scale copper smelting should not be discounted" (Bourke, 2001: p. 144).

Particularly in the Levant, where over-rigid typologies of organizational states, such as chiefdoms, are scarcely inferable, we can suggest that the broader concept of middle-range societies with distinctive developmental features appears more appropriate (Stein, 1998: p. 47). In line with that, researches on production, consumption, rituals and exchange may be employed as means to explore interrelationships between different aspects of societies, by analyzing archaeological data to investigate steps and dimensions of ancient social organization (Philips, 2001: p. 166).

\section{The Early Bronze Age and the Archaeological Setting of Tell es-Sa'idiyeh}

The notion of Early Bronze Age (EBA) city states in the southern Levant "was never actually demonstrated; it was simply assumed" (Philips, 2001: p. 163). As a matter of fact, second millennium BC urban models by extension have largely been adopted forinterpreting remains of-older by several centuries-Early

${ }^{1}$ This work was performed in 2004 for the MSc in Analysis and Technology of Archaeological Materials of the UCL Archaeology Institute in collaboration with the British Museum of London. 
Table 1. Stratigraphy of Tell es-Sa'idiyeh in relationship with the analyzed samples (after the stratigraphy by Tubb; pers. Com.).

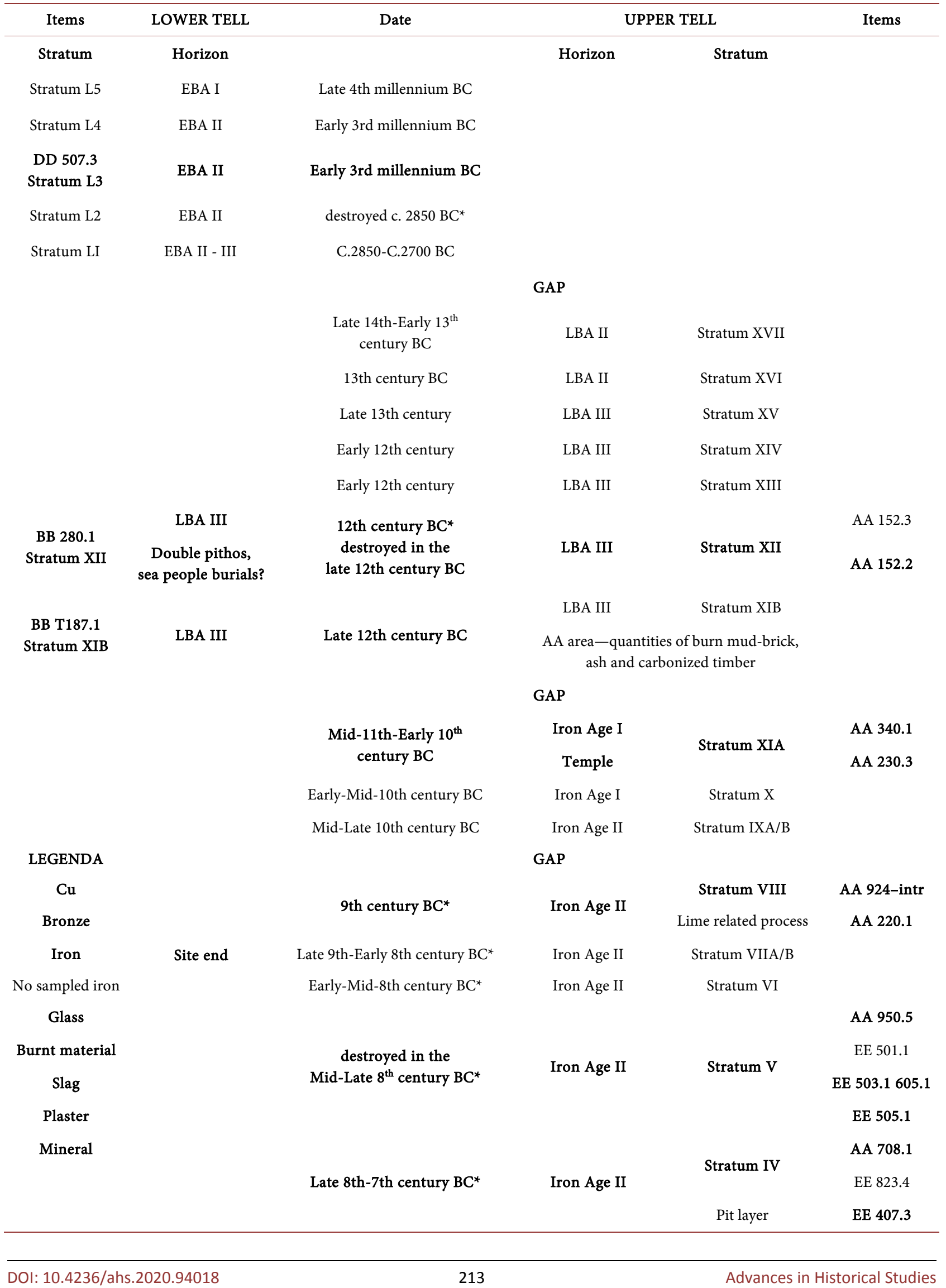




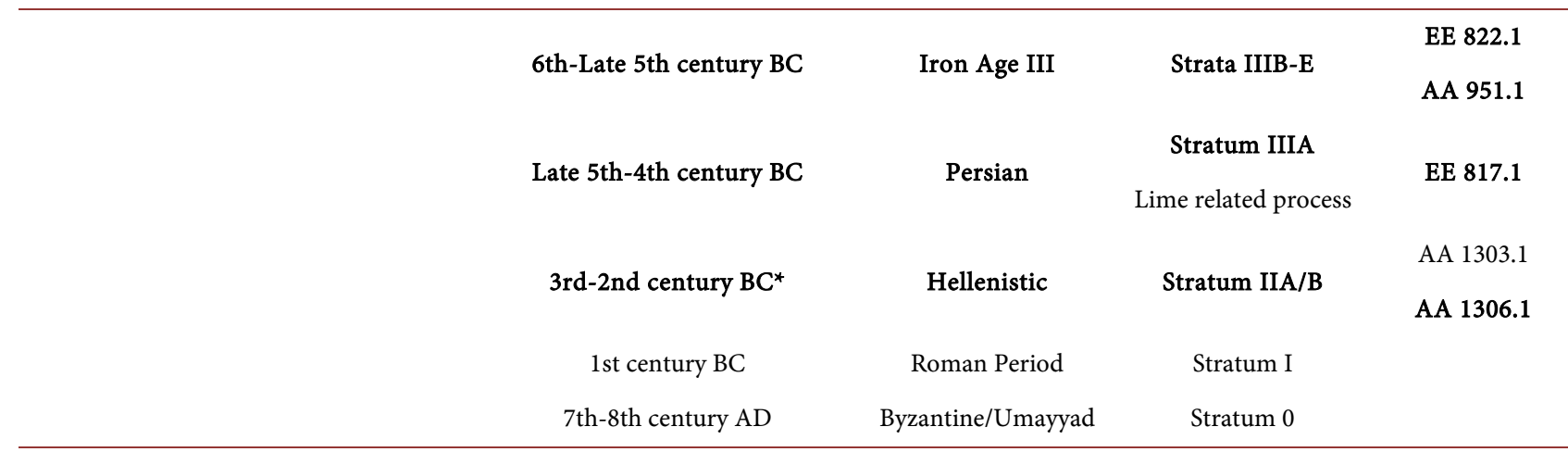

${ }^{*} \mathrm{C} 14$ datation in combination with conventionally derived pottery dates. It would be possible that dates and views will be subject to revision once that the whole site database will be compiled and analysed.

Bronze Age walled settlements (Finkelstein, 1995: p. 55; De Miroschedji, 1999: p. 12). The resultant picture of the EBA city states was a scattered number of hierarchical, territorial, political and economic units, each of them organized inside and around a walled central place. However, recent researches stress that different developmental trajectories were operating in the various regions of the EBA Levant where production and distribution of pottery, and chipped stone in particular, suggest that some economical areas were performed at a far wider spatial level than supposed for the enclosed city state model (De Miroschedji, 1989: p. 734; Finkelstein and Gophna, 1993). Also, more international works indicate that a significant degree of economic activity could exist outside primitive political spheres of influence (Stein and Blackman, 1993; Wattenmaker, 1994; Potter and King, 1995; Levy, 1995), and a new trend emphasizes the need of researches aimed at unpacking the various components of social complexity rather than necessary oriented grouping them in a whole (Netting, 1990).

EBA settlements in Jordan appear mainly of village dimensions, notwithstanding, villages are both socially and economically more complex than generally assumed (Schwartz \& Falconer, 1994: p. 2). The contrast between clear evidence of coordinated large scale projects, such as defensive walls or water systems, and limited indications for the existence of organizational elites may also suggest that activities of public interest were undertaken and "financed" on a corporate basis.

Although the well-fed corpus of Jordan EBA IIII radiocarbon dates is not always easy to interpret, some strata are assigned to clear chronological horizons and by them, an estimate of absolute dates, based upon calibrated radiocarbon data, was drawn (Table 2) (Philips, 2001: p. 169).

Frequent gaps are observed in most of the Jordan sites and in one case, at Tall as-Sukhne, a significant walled EBA II settlement appears to have been occupied only intermittently (Chesson et al., 1995: p. 116). In the emerging picture of the Jordan EBA, highly visible mobile groups are observed and they may account that not necessary evidence of walled structures concerned sedentary agriculture communities requiring dramatic defenses (Philips, 2001: p. 192). Many of these structures, on the other hand, variously interpreted as temples, palaces, walls or 
Table 2. Estimate of absolute dates for EBAI-III based upon calibrated C14 measurements (after Philips, 2001: p. 169).

\begin{tabular}{cc}
\hline Period & Absolute dates BC \\
\hline Early EBAI & $3600-34 / 3300$ \\
Late EBAI & $34 / 3300-31 / 3000$ \\
EBAII & $31 / 3000-2850 / 2750$ \\
EBAIII & $2850 / 2750-24 / 2300$ \\
\hline
\end{tabular}

storage rooms, may also be part of architectural forms employed for structures filling a range of different functions (ibid: 177). This was suggested for instance for an EBA II multi-roomed installation at Tell es-Sa'idiyeh that included a 4 by $3 \mathrm{~m}$ sunken room with access by steps and remains of 1213 large jars, most likely employed to store olive oil. The presence in the same context of almost 200 pierced bivalve shells has led the excavators to suggest a possible employment as a sort of recording system may be linked to the storage activity (Tubb \& Dorrell, 1994: p. 63).

As frequently in Jordan, the settlement of Tell es-Sa'idiyeh presents a long sequence of occupations from at least the Early Bronze Age until the Roman period with gaps and long periods of squatter settling observed (Table 1). For the current research, major interesting phases concern: stratum L3 of the EBA II site on the low tell, area DD; LBA/Iron Age horizons between strata XII and XIB including both the site on upper tell, area AA, and the cemetery on the lower tell, area BB; Iron Age strata VIII and the adjoining V and IV and the Persian stratum IIIA, both exclusive of the upper tell.

\subsection{Stratum L3 of the EBAII Site}

On the Low Tell, by completing the removal of the LBA-southwestern areas BB and DD-cemetery, started by Pritchard, remains of an Early Bronze Age site, well-defined in stratum L2, and a number of higher and lower layers were partly brought to the light. Stratum L2 showed floors of white lime plaster and functional, articulate disposition of the rooms, in one case suggesting careful storage activities $^{2}$. Copper samples DD 507.3 of the assemblage under analysis were found into the lower stratum L3 $3^{3}$. The surface of stratum L3 contained little pottery sherds but large storage vessels were sunk into the floor. The copper samples were found in area DD500 associated with a sequence of filling materials used for terracing the slope in order to prevent the slippage of the walls (Tubb, 1988a: p. 57 and Figure 39).

\subsection{LBA/Iron Age Horizons between Strata XII and XIB}

On the Upper Tell, between the southern and the western parts of the Prit${ }^{2}$ See above pag. 4.

${ }^{3}$ As an example to better understand the excavation code inside the reference number of samples, in DD 507.3: DD is relative to the area of finding, 500 to the context, 7 to the unit inside the context and 3 to the stratum inside the unit. 
chard's trenches, area AA, extensively dug during the last decade in order to complete the occupational sequence below the lowermost stratum (VII) reached by the American team, has showed to have played a pivotal role in the site dynamics. Thanks to its position around the top of the mound, area AA reported the almost whole sequence of the site, since it showed to be settled also during the poor occupational phases, diffusely observed in the rest of the areas.

Stratum XII on the Upper Tell, associated with the LBA cemetery on the Low Tell, reported clear evidence of Egyptian influences particularly referred to the well documented lowermost horizon (Tubb, 1988a: p. 41).

Stratum XII and the immediately successive stratum XIB into the stratigraphy are followed by the most consistent of the gaps observed at Tell es-Sa'idiyeh. The gap is related to the Bronze Age/Iron Age transitional period and possibly may account of the Jordanian involvement in the collapse of the Late Bronze Age empires of the Near East and Egypt. The architecture of stratum XII consistently reflects techniques and typologies of Egyptian tradition and in the south-eastern corner of area AA the remains of an impressive Egyptian residency, discovered in area EE, may exhaustively account for a likely temporary Egyptian control of Tell es-Sa'idiyeh, as well as possibly of a good part of the Jordan Valley (Tubb, 1988a: p. 40ff; Tubb et al., 1996: p. 27). The LBA site was encircled by massive walls and fed by a sophisticated water system, both observed in a number of consistent remains. An intense destruction layer, dated to the mid-twelfth century BC, marked the end of the deposit of stratum XII (Tubb et al., 1996: p. 27).

Furthermore, evidence of a not yet fully defined presence at Tell es-Sa'idiyeh of mostly coastal dynamic groups famed as "Sea Peoples", which appear to have largely contributed to the downfall of the LBA Mediterranean Cultures, makes the site quite indicative to the analysis of that crucial technological and cultural change. History and provenience, or names as well, of this group, are still ambiguously documented so entering in the details of this train would be misleading for the topic of this research but some remains of the LBA III cemetery in the area BB of the Sa'idiyeh Low Tell deserve a brief regarding note. In the funerary layers of this area assigned to stratum XII, in addition to the large typology of pits and build tombs observed, about ten depositions have been found interred within coffins obtained by joining two huge jars each, shoulder by shoulder removing their necks (Tubb, 1988a: p. 60 Figure 42). Contrarily to the rest of the cemetery, every of those "double pithos" burials showed evidence of having been robbed and disturbed in antiquity, likely soon after deposition itself (Tubb, 1990: p. 29). According to Tubb, this may account that: "the Sa'idiyeh double pithos burials represent the interments of an alien group within the population, most probably Sea Peoples, the graves of whom might not have been considered as inviolate as those of the local population" (Tubb \& Chapman, 1990; Tubb \& Dorrell, 1993; Tubb et al., 1997). Furthermore, if, according to Tubb, sea peoples of 
Aegean origins have been at least one of the agents for the uninterrupted copper production in Palestine and Transjordan through the age change at the end of the second millennium BC (Tubb, 1988b: p. 25861), the presence of such burials may suggest that some of them were settled or employed at Tell es-Sa'idiyeh as metalworkers without any real integration occurred.

Three samples of this assemblage are specifically assigned to this stratum, the copper sample BB 280.1 from the low tell, and the iron samples AA 152.1 and 2 from the upper tell. At the same time, bronze sample BB T187.1, from a tomb of stratum XIB, may be likely joined to this group since remains of stratum XIB appears to be very similar with that of stratum XII, suggesting an immediate occupation following the destruction (Tubb, 1988a: p. 40). Moreover, as observed by Pritchard (1980: p. 1), Tubb reports that the homogeneity of the silt in the burial levels on the Low Tell in the majority of cases made impossible to establish the exact level of the graves (Tubb, 1988a: p. 59), particularly regarding to the simple pit burials where the bronze sample BB T187.1 come from (ibid: 77). Two of the samples were found in stratum XIA, both in area AA, the iron sample 340. 1 and the sample 230.3, probably of geologic origin, but, unfortunately, such material is not very interesting for a contextual reading, differently from the stratum that appears to be a holy complex stressing consistent changes occurred in the site setting ${ }^{5}$ (Tubb, 1988a: p. 37ff).

\subsection{Iron Age Strata VIII and the Adjoining V, IV and IIIB-E}

Stratum VIII, after a long phase of gaps and squatter occupations, exclusive of the Upper Tell, testify of a relevant and resettled human activity in the area. According to Tubb, the deposit of stratum VIII, placed within the latter half of the 9th century BC, may be seen as a waste layer of some industrial activity covering with variable thickness what remained of the underlying stratum IX. The white predominance observed in the coloration of such layer and the large occurrence of grossly distorted sherds, sometimes vitrified by intense heat, was suggestive of lime-related activities (Tubb, 1988a: p. 33). That inference is also supported by one of the samples of the assemblage from area AA assigned to stratum VIII that analysis revealed to be a fragment of lime plaster, AA 220.1. Also iron fragment AA 924.1 was assigned to stratum VIII but already after a first visual analysis of the cut section, the sample was considered intrusive because of an unusual excellent state of conservation (Thilo Rehren, pers. comm.). The intrusive provenience of sample AA 924.1 was subsequently confirmed by chemical analysis.

The Iron Age II strata V and IV are particularly interesting. Stratum V was found to be associated with a dense layer of burnt mudbrick debris and ash, diffusely observed through areas AA and EE and dated to the late eight century BC. It would appear to represent a destruction level, as in the opinion of Tubb, likely performed by Assyrians (pers. comm.). The following stratum IV is substantially characterized by the large occurrence of circular bins and pits dug into the de-

${ }^{5}$ Stratum XIA was found considerably disrupted by depressions and pits associated with stratum X. 
struction debris of stratum $\mathrm{V}^{6}$ (Tubb \& Dorrell, 1991: p. 74).

Assigned to stratum IV, a room brought to the light during the last season appears associated with the phase of the bin storage. The most consistent group of my samples, and the most interesting of them as well, come from the horizons of strata V and IV: from stratum V, in area EE the iron samples 501.1, 503.1 and 605.1, more one slag lump EE 505.1 and finally the samples in the bag AA 950.5, burnt concretions of different materials joined together by intense heat; from stratum IV, iron samples EE 407.3 and 823.4 more a group of about eighteen slag lumps AA 708.1. From the Late Iron Age stratum IIIB-E comes the bronze sample EE 822.1 and the glass fragment AA 951.1.

\subsection{Persian Stratum IIIA}

A massive sub-rectangular cut in the northern parts of areas AA and EE, which had destroyed the whole sequence from strata IV to VII, was attributed to stratum IIIA, the Persian period. Aim of the large cut appeared to have been the installation of a kiln in EE 800 that was found associated with a heavy deposit of layered waste and ash, suggesting the hypothesis of plaster production (Tubb \& Dorrell, 1991: p. 74ff). Such hypothesis is further supported by the only sample of the assemblage coming from the area of the kiln context that analysis revealed to be a fragment of lime plaster EE 817.1. The plaster lump was found into the fill of a waste deposit placed at the opposite front of the wall adjoining to the kiln.

The most recent of the samples, two iron fragments AA 1306.1 and 1303.1, come both from stratum IIA/B of area AA 1300. Stratum IIA/B of this area, south of the Persian palace, is assigned to the Hellenistic period. During the last dig seasons, the stratum was divided into two phases because an intermediate layer of black ash and burnt mudbrick debris was observed between the Pritchard's Hellenistic building and the remains of an earlier architectural level with different line and orientation (Tubb \& Dorrell, 1994: p. 52). The iron samples are strongly corroded and unfortunately not very interesting for this research.

\section{Introduction of Samples and Research Methodology}

The twenty-two bags of finds forming the assemblage at disposal for this research contained different numbers of samples or fragments of them. All the bags, but four ${ }^{7}$, were sampled one or more times in order to obtain suitable slices of material for the sample preparation. Sample blocks were then analyzed both for their chemical composition and microscopic structure in the laboratories at the Institute of Archaeology of University College London. Optical and chemical analyses were performed by optical microscope; energy dispersive spectrometry (EDS), attached to a scanning electron microscope (SEM) type JEOL 35; X-ray

${ }^{6}$ Of which, ninety-eight excavated by Pritchard (1985: pp. 39-42) and six during the last campaigns (Tubb \& Dorrell, 1991: p. 74).

${ }^{7}$ The four not sampled bags contain iron fragments strongly corroded; see the Appendix: iron samples AA 152.3, EE 501.1, EE823.4 and AA 1303.1. 
fluorescence spectrometry (XRF); and in one case, by wavelength-dispersive $\mathrm{X}$-ray spectrometry and electron microprobe (EPMA).

Unfortunately, all the metal samples were strongly corroded and, therefore, not very informative and unsuited to be analyzed by etching on what concerns microstructure and manufacturing techniques. On the contrary, slag and vitreous materials, notably plaster samples, showed to be very interesting since they appeared to confirm what contextual data had previously suggested.

To avoid interruptions through the text, before starting with analysis of the items and find contexts, is worth to stress that data without any other indications of source will be intended as drawn from unpublished Sa'idiyeh excavation reports, delivered by Jonathan Tubb for this research as personal communications.

\subsection{Copper and Bronze from the Low Tell Bronze Age Cemetery}

All the copper-base items analyzed for this research are strongly corroded and therefore unsuited to be investigated in order to identify working or shaping technology. Notwithstanding, the relevant copper and bronze inventory of the Sa'idiyeh cemetery and the occurrence in there of what have been interpreted as remains of Sea People burials, deserve some notes about the bronze production in the Jordan Valley during the last stages of the Late Bronze Age and the beginning of the Iron Age. In the opinion of Tubb, following Pritchard (1968: p. 103), bronze production and Sea People presence in the Levant could be linked (Tubb, 1988b: p. 25660).

Excavations at a number of Palestinian and Transjordanian sites report evidence of LBA and Iron Age bronze production ${ }^{8}$. The centers appear to have been initially under Egyptian control when individuals or groups of Sea Peoples were employed as metalworkers (ibid: 55). At the time when the Egyptian control was weakening, those sites appear to be strongly garrisoned easily in order to save such important industry. Following the sea battles of year 8 of Ramses III (Gardiner, 1947: p. 24), the settlement of groups of Sea Peoples on the Canaanite coast does not seem to interrupt bronze production even at the sites still under Egyptian control. There, also the Philistine presence was actually attested at least by pottery. With the decline of the Egyptian power on the region, in the 12th century BC, Philistines seem continuing and, by opening new centers, indeed incrementing bronze production till the 11th century $\mathrm{BC}$. The conjecture is strongly supported by both the quantitative decline of the bronze production in Iron II contexts and the quite absence of remains of Palestinian production centers following the defeat of the Philistines by David at the beginning of the 10th century BC.

The Jordan Valley sites such as Tell Sa'idiyeh and Tell Deir 'Alla seem actually left to the management of their own populations. At both the sites, stratigraphy concerning the Early Iron Age is very confused with long periods of disconti-

${ }^{8}$ For the listing sites, see Tubb (1988b: pp. 258-259). 
nuous occupations. At Deir 'Alla, in this phase (B), remains of furnaces and slag were found associated with pits and workshop areas (Franken, 1969: 201). According to Franken (ibid), the site was seasonally used by seminomadic itinerant metalworkers.

\subsection{Slag and Iron from the Upper Tell and Hypothesis of Iron Age Metalworking}

According to Bachmann, "The use of ores is invariably related to the formation of slags" (Bachmann, 1982: p. 9); as ores are purer as less slags will be formed. In the process of iron smelting, slag is an important factor. Slags, as little drops or big lumps, consist mostly of compounds formed by iron oxide ( $\mathrm{FeO}$ or $\mathrm{Fe}_{2} \mathrm{O}_{3}$ ), silica $\left(\mathrm{SiO}_{2}\right)$ and lime $(\mathrm{CaO})$. In addition, variable amounts of $\mathrm{MgO}, \mathrm{Al}_{2} \mathrm{O}_{3}, \mathrm{P}_{2} \mathrm{O}_{5}$ and alkali oxides are also present, but also inclusions more as a rule than an exception. However, composition and properties of slags are both influenced by a wide range of factors: ores, gangue, fluxes, furnace, fuel, process and cooling conditions and also weathering (Bachmann, 1982: p. 10). With the aid of charcoal, iron may be reduced from pure iron oxides already at about 800ÆC., considerably below the melting point of the metal (1540ÆC.) (Tylecote, 1992: p. $48 \mathrm{ff})$. But iron ores are rarely pure; they are mostly mixtures of iron oxides and "gangue", or unwanted minerals. In order to reduce pure iron, oxygen is removed from the ores by chemical reaction with the carbon of the fuel, wood and charcoal', but gangue has to be removed as much as possible by liquation at or above the temperature (c. 1150ÆC.) at which the fluid slags start to drain away from the still solid iron (Tylecote, 1992: p. 48ff).

A first important distinction between slags is relative to the processes of smelting and smithing as different steps of the iron production. Smelting slags are the waste products of iron reduction processes from ores to raw "bloom", or "wrought" iron. Bloom is a solid sponge-shaped mass of iron, in which a good deal of slaggy material is still entrapped. Smithing slags come from refining and shaping processes and, on this ground, are distinguished between primary or secondary type. Before the modern invention of the reverberatory, or "puddling", furnace, unwanted material inside the bloom was removed by repeated hammering, forging and heating, at lower temperatures than smelting, producing iron bars as final product and primary smithing slags as waste. Primary smithing slags chemically and physically resemble smelting slags and cinders and distinction among them is very difficult ${ }^{10}$. Finally, secondary smithing slags are waste products of shaping iron by working iron bars, and they consist mainly of fairly pure oxidized iron (Bachmann, 1982: p. 31).

In antiquity, metals were so precious and carefully salvaged that likely any smallest bit was systematically recovered in order to save them as recycling ma-

${ }^{9}$ In the opinion of Bachmann, only wood and charcoal were employed in antiquity for heating and reduction processes, except the use of coal for smelting iron in China probably earlier the 4 th century AD (Needham, 1958; Bachmann, 1982: p. 10).

${ }^{10}$ Infusible or partially fused mass produced at a particular temperature of the furnace operation. 
terials. As a result, in the archaeological records, slags are often the only witnesses of ancient metallurgical processes (Bachmann, 1982: p. 3). However, slags better report both occurrence and degree of past metal working than artefacts, not necessary of local origin and generally too precious to be sampled or alternately too corroded to be informative.

The latter case is that one of the iron assemblage of Tell es-Sa'idiyeh. Notwithstanding, some notes about iron finds at Tell es-Sa'idiyeh are worth to be drawn. In many of the graves of the LBA III cemetery, dated to the 13th and 12th centuries $B C$, iron objects were found in relatively high proportion and often alongside bronze items (Tubb, 1988b: p. 255). Iron finds were normally weapons such as daggers, knives and arrowheads but also some iron trinkets were collected. Through most of the regions of the old world, the LBA III inventory of iron finds is continuously enriched with new discoveries mostly supported by major careful in collecting samples but also by a different approach to the emergence of the iron technology. The completion of the iron production setting was perhaps one of the major task of the mankind but iron ores, differently for instance from tin ores, are far and away the most common ores, widely distributed everywhere. In the confuse centuries preceding the transitional period between Bronze and Iron Ages, various traditions of metal working may have approached to the iron technology with different background and from different reasons, presumably linked for the most to the complexity of the tin supply.

Samples EE 505.1 (Figure 1) and AA 708.1 (Figure 2), identified as slags in situ and then by XRF and SEM analysis, have a basic composition of silica $\left(\mathrm{SiO}_{2}\right)$, lime $(\mathrm{CaO})$ and iron oxide $\left(\mathrm{FeO}\right.$ or $\left.\mathrm{Fe}_{2} \mathrm{O}_{3}\right)$. They come from both different areas and different periods of the Iron Age II adjoining strata $\mathrm{V}$ and IV, respectively sample EE 505.1 from stratum V and the bag AA 708.1 from stratum IV.

All the grey brownish lumps from bag AA 708.1 show to be both physically and chemically very close each other. The XRF analysis of the eight samples, reported in the XRF table in Figure 2, shows consistent averages of iron oxide (FeO) swinging between $54.8 \%$ of sample 7082 and $81.6 \%$ of sample $708 \mathrm{~b}$.

Silica $\left(\mathrm{SiO}_{2}\right)$ content is at the contrary low with an average range for silica between $8 \%$ of sample $708 \mathrm{~b}$ and 14 of sample 7086 , while lime $(\mathrm{CaO})$ is higher than in many early iron slags, with between 3.4 of sample $708 \mathrm{~b}$ and 15.5 of sample 7082.

All of them show dendrites of wüstite $(\mathrm{FeO})$ in a slag matrix with inclusions of particles of metallic iron ${ }^{11}$. Such consistent presence of metallic phases inside the dendrites could suggest strongly reducing conditions indicative of a smelting process. Nevertheless, metallic iron may well form by wüstite losing oxygen by chemical reaction with carbon monoxide during primary or secondary smithing processes. On the other hand, a secondary smithing origin for the samples is also suggested by the high content of iron oxides.

The SEM analysis of large areas of the grey brownish slag lump EE 505.1, summarize in Figure 1, reveals quite standard averages of iron oxide $(\mathrm{FeO})$

\footnotetext{
${ }^{11}$ Wüstite is a common mineral in bloomery slag, but it may occur also in other typologies.
} 


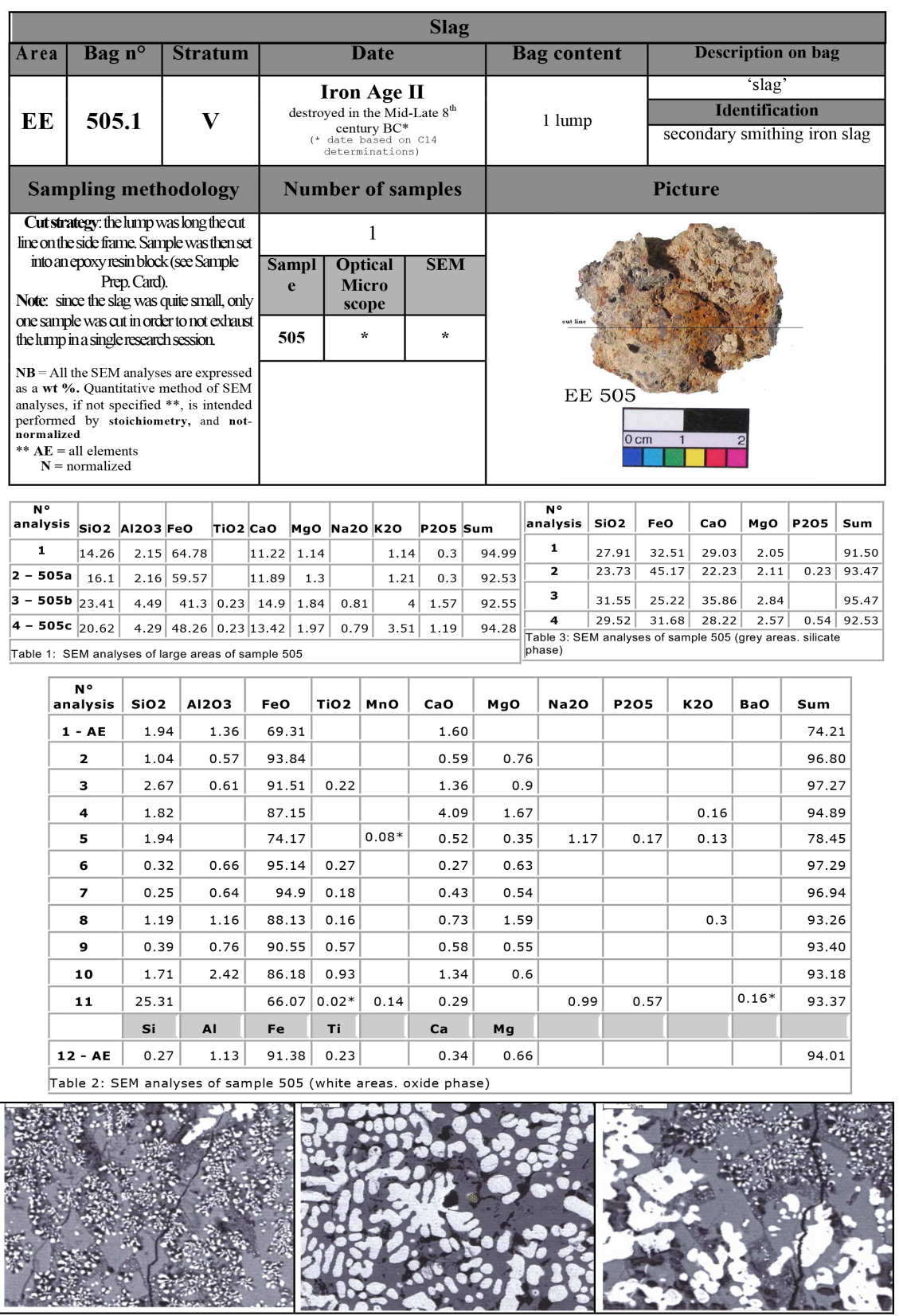

Figure 1. Sample EE 505.1 and analysis.

and silica $\left(\mathrm{SiO}_{2}\right)$, respectively of $53.5 \%$ and $18.6 \%$, and a high amount of lime $(\mathrm{CaO})$ with an average of nearly $13 \%$. Amount of lime is higher in the grey silicate matrix and suggests occurrence of a Femonticellite phase ${ }^{12}$. Such high amount of lime may develop by contamination with the furnace lining or by the voluntary addition of a calcium-base compound as a component of smithing. Microscopic analyses of the sample show widely distributed dendrites of wüstite $(\mathrm{FeO})$ and localized areas of magnetite $\left(\mathrm{Fe}_{3} \mathrm{O}_{4}\right)$. No metallic phases are observed within the dendrites or in the matrix.

${ }^{12}(\mathrm{Fe}, \mathrm{Mg}, \mathrm{Mn}) \mathrm{CaSiO}_{4}$ or $(\mathrm{Fe}, \mathrm{Mg}, \mathrm{Mn}) \mathrm{O} \cdot \mathrm{CaO} \cdot \mathrm{SiO}_{2}$, more correctly written with the general formula $\mathrm{RO} \cdot \mathrm{CaO} \cdot \mathrm{SiO}_{2}$, with $\mathrm{R}=\mathrm{Fe}, \mathrm{Mn}, \mathrm{Mg}, \mathrm{Zn}$ (Bachmann, 1982: p. 14). 


\begin{tabular}{|c|c|c|c|c|c|}
\hline Area & $\overline{\text { Bag }}$ & Stratum & Date & Bag content & Description on bag \\
\hline \multirow{3}{*}{ AA } & \multirow{3}{*}{708.1} & \multirow{3}{*}{ IV } & \multirow{3}{*}{$\begin{array}{c}\text { Iron Age II } \\
\text { Late 8th-7th century BC** }\end{array}$} & \multirow{3}{*}{$\begin{array}{l}7 \text { lumps + about } 10 \\
\text { small lumps + powder }\end{array}$} & "slag' \\
\hline & & & & & Identification \\
\hline & & & & & $\begin{array}{l}\text { secondary smithing iron } \\
\text { slag }\end{array}$ \\
\hline \multicolumn{3}{|c|}{ Sampling methodology } & Number of samples & \multicolumn{2}{|c|}{ Picture } \\
\hline \multirow{7}{*}{\multicolumn{3}{|c|}{ 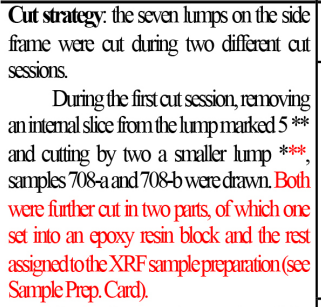 }} & 8: & \multirow{12}{*}{ AA708.1 } & \\
\hline & & & First cut session: & & \\
\hline & & & 708-b - 8 (fragment) & & \\
\hline & & & $\begin{array}{l}\text { Second cut session: } \\
\text { Weight in grams: }\end{array}$ & & \\
\hline & & & $\begin{array}{l}708-1-121,160 \\
708-2-32,85\end{array}$ & & \\
\hline & & & $\begin{array}{l}708-4-65 \\
708-6-81,50\end{array}$ & & \\
\hline & & & $708-7-40,67$ & & \\
\hline \multirow{5}{*}{\multicolumn{3}{|c|}{$\begin{array}{l}\text { During the second cut session, all the } \\
\text { other six lumps were sampledremoving an } \\
\text { intemal slice each ****. Every slice was } \\
\text { further aut in two parts, of which one } \\
\text { assignedtotheXRF samplepreparation and } \\
\text { the oother one used for microscopic } \\
\text { observations. Samples 708-1 and } 708-6 \\
\text { were then set into epoxy resin blocks (see } \\
\text { Sample Prep. Carc). }\end{array}$}} & 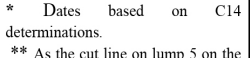 & & \\
\hline & & & $\begin{array}{l}\text { side frame. } \\
* * * \text { Not on the side frame. One half } \\
* * \text { ton }\end{array}$ & & \\
\hline & & & $\begin{array}{l}\text { used for sampling and the other one } \\
\text { in the teaching collection of the UCL } \\
\text { Institute of Archaeology. }\end{array}$ & & \\
\hline & & & $\begin{array}{l}\text { **** As an example for everyone, } \\
\text { the cut lines on lump } 4 \text { on the side } \\
\text { frame }\end{array}$ & & \\
\hline & & & & & \\
\hline
\end{tabular}

\begin{tabular}{|c|c|c|c|c|c|c|c|c|c|c|c|c|c|}
\hline \multirow[b]{2}{*}{$\begin{array}{l}\text { Sam } \\
\text { ple }\end{array}$} & \multirow{2}{*}{$\begin{array}{c}\text { Optical } \\
\text { Microsco } \\
\text { pe } \\
\end{array}$} & \multirow[t]{2}{*}{ SEM } & \multirow[t]{2}{*}{ XRF } & \multirow[b]{2}{*}{$\begin{array}{c}\mathbf{N}^{\circ} \\
\text { analysis }\end{array}$} & \multirow[b]{2}{*}{ Phase } & \multirow[b]{2}{*}{$\mathrm{SiO2}$} & \multirow[b]{2}{*}{$\begin{array}{c}\text { Al2O } \\
3\end{array}$} & \multirow[b]{2}{*}{$\mathrm{FeO}$} & \multirow[b]{2}{*}{$\mathrm{CaO}$} & \multirow[b]{2}{*}{ K2O } & \multirow[b]{2}{*}{ P205 } & \multirow[b]{2}{*}{ NiO } & \multirow[b]{2}{*}{ Sum } \\
\hline & & & & & & & & & & & & & \\
\hline $708-\mathrm{a}$ & $*$ & * & * & 1 & Area - fayalite & 18.99 & 1.81 & 44.82 & & 1.49 & 0.86 & $0.16 *$ & 67.97 \\
\hline $708-b$ & * & $*$ & $*$ & 2 & Area - silicate matrix & 42.93 & 1.55 & 25.97 & & 3.33 & & $0.16 *$ & 73.78 \\
\hline $708-1$ & * & & $*$ & 3 & Area - iron oxide ${ }^{1}$ & 6.95 & 2.27 & 85.32 & & 0.67 & & 1.02 & 96.23 \\
\hline $708-2$ & * & & * & 4 & Point - iron oxide ${ }^{1}$ & 11.78 & & 68.21 & & 0.53 & & & 80.52 \\
\hline $708-3$ & $*$ & & $*$ & 5 & Point - wüstite & & 0.77 & $\mid 93.07$ & & & & & 93.84 \\
\hline $708-4$ & $*$ & & $*$ & & & Si & & $\mathbf{F e}$ & $\mathrm{Ca}$ & & & & \\
\hline $708-6$ & & & & $6-A E$ & Point - wüstite & & & 70.86 & 2 & & & & 72.86 \\
\hline & $*$ & & $*$ & $7-A E$ & Point - iron oxide ${ }^{1}$ & 1.12 & & 69.73 & 2.5 & & & & 73.35 \\
\hline $708-7$ & $*$ & & $*$ & 8-AE & Point - iron oxide ${ }^{1}$ & 0.26 & & 69.95 & 3.93 & & & & 74.14 \\
\hline \multirow{2}{*}{\multicolumn{4}{|c|}{$\begin{array}{l}\text { NB = All the SEM analyses are } \\
\text { expressed as a wt } \% \text {. Quantitative } \\
\text { method of SEM analyses, if not } \\
\text { specified } * * \text {, is intended by } \\
\text { stoichiometry and } \text { not-normalized } \\
* * \text { AE = all elements }-\mathbf{N}=\text { normalized }\end{array}$}} & \multicolumn{10}{|c|}{ SEM analyses of sample AA 708_a } \\
\hline & & & & \multicolumn{10}{|c|}{$\begin{array}{l}1 \text { When analysis performed on an iron oxide formation, such as wüstite or magnetite, } \\
\text { does not match with the microstructure }\end{array}$} \\
\hline
\end{tabular}

\begin{tabular}{|c|c|c|c|c|c|c|c|c|c|}
\hline $\mathrm{N}^{\circ}$ an. & Phase & $\mathrm{SiO} 2$ & Al203 & $\mathrm{FeO}$ & $\mathrm{CaO}$ & K2O & P205 & $\mathrm{NiO}$ & Sum \\
\hline 1 & Area & 0.34 & & 75.76 & 2.04 & & & & 78.14 \\
\hline 2 & Area - iron oxide ${ }^{1}$ & 0.26 & & 75.17 & 1.96 & & & & 77.39 \\
\hline 3 & Area - iron oxide ${ }^{1}$ & 2.21 & & 69.87 & 0.5 & & & 0.41 & 72.99 \\
\hline 4 & Area - iron oxide ${ }^{1}$ & 2.23 & & 69.9 & 0.59 & & & $0.23 *$ & 72.72 \\
\hline 5 & Area - iron oxide ${ }^{1}$ & 0.78 & 0.68 & 83.36 & & & & & 84.82 \\
\hline 6 & Area - corrosion & 5.45 & 0.28 & 41.83 & & 0.23 & 0.42 & $0.13 *$ & 48.21 \\
\hline 7 & Point - wüstite & & & 90.27 & & & & & 90.27 \\
\hline 8 & Area & 2.52 & & 71.86 & & & & $0.30 *$ & 74.38 \\
\hline
\end{tabular}

Figure 2. Samples AA 708.1 and analysis.

The slag lump from the bag EE 505.1 comes from a deposit found at the corner of the excavation trench in area EE 500 of stratum V. Such deposit reached from the top of level 501.2 till the bottom of the stratum. The deposit showed vague outlines and reported several layers of dark brown, beige and black material with pieces of burned mud bricks and white ash in it. Following the excavation report by Tubb, the slag lump was the only sample taken for analysis from the deposit 505.1. Nevertheless, two of the bags from stratum $V$ with iron items, EE 501.1 and EE 503.1, also come from the area eastwards of wall A in trench 500. 
In the different layers of such part of area $500^{13}$, belonging to the same Iron Age II horizon of stratum V, finds and disposition of the rooms may suggest that some kind of production was performed. Deposit 505.1 appears as a discard corner where wastes of production as slag, plaster lumps, mud brick fragments and ash were helter-skelter collected.

The soil of layer 501.1 showed no evidence of ash, chalk or mud brick but some big sherds were placed in horizontal position and a stone with two groves crossing each other was found associated with another big stone suggesting an employ for the former as sharpening tool.

Furthermore, about $5 \mathrm{~cm}$ of an ashy grey layer was discovered between stratum 501.1 and the lower stratum 501.2, where loose soil and spots with silica concentration were observed.

Presumably, ancient small productions did not leave so many wastes as the modern workshops currently do, since the number of consumers was narrow, easily of household dimension, and the supply of raw materials was all but systematic. Particularly for stratum V where a dense layer of burnt mudbrick debris and ash through all the Upper Tell suggests a destruction layer, likely performed by Assyrian, the supply of raw materials could have been intermittent if not hardly feasible. In line with that, it is possible that workshops had short life and, within a same cultural horizon, working areas or parts of them could be frequently reused for different productions.

The interpretation of such dense-burnt debris and ash-layer between strata $\mathrm{V}$ and IV as a destruction level is emphasized by the SEM and XRF analysis of the samples from bag AA 950.5. XRF analysis of the three small grey concretions reports silica $(\mathrm{SiO})$, lime $(\mathrm{CaO})$, soda $(\mathrm{NaO})$, magnesia $(\mathrm{MgO})$ and iron oxide $(\mathrm{FeO})$ as main components but SEM analysis of one sample of them shown different materials, such as plaster, minerals and limestone, joined together by a contemporary submission to intense heat. The destruction layer is dated to the Mid-Late 8th century BC (Table 2).

About fifteen kilometres south east of Tell es-Sa'idiyeh, extensive remains of iron smelting and smithing were discovered at the site of Tell Hammeh (azZarqa), on the south side of the Wadi Deir 'Alla, dating back to approximately 1000-750 BC (van der Steen, 1997, 2001, 2003; Veldhuijzen, 1998, 2000; Veldhuijzen and van der Steen, 1999, 2000). There, an impressive iron production was documented with finding of some 350 tuyère fragments, charcoal, remains of furnace and 400 to $500 \mathrm{~kg}$ of slag from only $9 \%$ of the estimated area involved in metallurgy (van der Steen, 2003: p. 102). The slags from Tell Hammeh appear to be manly of smelting and primary smithing types with peculiar elemental compositions (ibid: 103). Since the Hammeh slags and the samples from Tell esSa'idiyeh appear to belong to different steps of the iron production, comparison between both the finds could be approached only after the completion of analysis of the Hammeh slag assemblage in order to identify secondary smithing slags

\footnotetext{
${ }^{13}$ Notably 505, 501 and the common stratum 503 .
} 
in there. Notwithstanding, evidence of regular smelting and primary smithing activities in the Jordan Valley dating from no later than 750 BC may contribute to a better understanding of early iron technology regional dynamics also regarding more limited remains such as the Sa'idiyeh finds.

Through all the areas where it was distinguished, stratum IV was found to be associated with roughly circular pits or bins, dug into the destruction layer of stratum V (Pritchard, 1985: pp. 39-42; Tubb, 1990: p. 223; Tubb \& Dorrell, 1991: p. 74). Most of the pits held a fibrous fill containing crystallized plant remains, likely chaffy elements from crop processing, and, according to Tubb (1990: p. 22), so filled they might be served as storage containers for animal fodder. Nevertheless, mixed fills were also observed containing white chaffy material, animal bones, flint and, in the case of the pit AA 708.1, some lumps of slag showing similar structures and compositions. Pit 708.1, taking the form of an oval trench, was cut vertically into yellow bricks strata and provided of a level of rocks and pebbles above the bottom. A scarab of faience or glass was found in association with the slag (Tubb, 1988a). No associated structures related to the bins were reported by Pritchard or by the Tubb's expedition till the last dig season, when an unfinished sounding by Pritchard, beneath the courtyard of the stratum III Persian building, was further investigated. Below a number of distinctive surfaces, stratum IV was achieved. At this level, a mudbrick installation, only a corner of which was found, shown brick sizes and weathering evidence very close to what concern the rectangular brick-lined storage bins dug by Pritchard within the pit area to the west (Pritchard, 1985: p. 401, Figure 180). In the opinion of Tubb (pers. comm.), such remains appear to be associated with the control of the bin storage.

\section{Conclusion}

The reconstruction of contexts and working technologies at Tell es-Sa'idiyeh discussed here should be considered inherently valid within the limits of the available data. The samples assembled for this research are quantitative too small by material to be representative or, in some cases, even only indicative. On the other hand, particularly regarding the slag group, their occurrence in stratified waste contexts may exclude any intrusive hypothesis. The site with a long life and a strategic position was surely subject to most of the influences, as well as of the pressures, operating through the Jordan Valley. Nevertheless, attempts to reach consensus on a broad regional synthesis are not easy. Too often regional studies may survive simply because the fragmentary nature of the data lends itself to the construction of hypotheses grounded as much by the lack of evidence than by its availability. In order to draw a framework of the-archaeologically quite virgin but historically very complex-Jordan Valley dynamics, it is strongly necessary firstly drawing complete, possibly open, databases for every site.

The development of metallurgy in Jordan, and more generally in Levant, appears having followed independent patterns compared to what Syria and Anatolia concern. At the same time, what was interpreted as a Jordanian late to the rest 
of the Near East in developing of complex social organizations and in adoption of new technologies was indeed lacking of both data and patterns suitable for interpreting different lines of development. On the contrary, new methodologies of dig and major careful in both collection and analysis of data, as well as objects, showed that in Jordan some technologies such as the iron production, may have developed earlier than in other parts of the Near East and Europe, as suggested by the Hammeh excavation as an example. There, during every season of dig an archaeometallurgy expert is constantly present (Veldhuijzen, pers. comm.), in order possibly to better save and collect data and from them inferring, directly in situ, new research strategies. In this way, more coherent analysis may be performed in order to identify technological degree of a specific culture and the strategy adopted for achieving it, including the different steps involved in production.

\section{Acknowledgements}

Many thanks to ThiloReheren and Jonathan Tubb.

\section{Conflicts of Interest}

The author declares no conflicts of interest regarding the publication of this paper.

\section{References}

Bachmann, H. G. (1982). The Identification of Slag from Archaeological Sites. London: Occasional Publication.

Bourke, S. (1998). A Chalcolithic Origin for the Bronze Age State Systems in the Southern Levant: Evidence from Teleilat Ghassul, Jordan. In R. Matthiae et al. (Ed.), First International Congress of the Archaeology of the Ancient near East. Rome: Università di Roma La Sapienza.

Bourke, S. (1999). Preliminary Report on the University of Sydney's Eighteenth and Nineteenth Seasons of Excavations at Pella (TabaqatFahl) in 1996/97. Annual of the Department of Antiquities of Jordan, 45.

Bourke, S. (2001). The Chalcolithic Period. In B. MacDonald, R. Adams, \& P. Bienkowski (Eds.), The Archaeology of Jordan (pp. 107-162).

Bourke, S., et al. (1995). Preliminary Report on a First Season of Renewed Excavations at Teleilat Ghassul by the University of Sydney, 1994. Annual of the Department of Antiquities of Jordan, 39, 31-64.

Chesson, M. S., Flender M., Genz, H., Hourani, F., Kuijt, I., \& Palumbo, G. (1995). Tell es-Sukhne North: An Early Bronze Age II Site in Jordan. Paléorient, 21, 113-123. https://doi.org/10.3406/paleo.1995.4612

De Miroschedji, P. (1989). Le processus d'urbanisation en Palestine au Bronze Ancien: chronologie et rythmes. In De Miroschedji (Ed.), L'urbanisation de la Palestine a l'age du Bronze Ancien (pp. 63-80). British Archaeological Reports, International Series 527. Oxford: British Archaeological Reports.

De Miroschedji, P. (1999). Yarmouth: The Dawn of City-States in Southern Canaan. Near Eastern Archaeology, 62, 2-19. https://doi.org/10.2307/3210719

Finkelstein, I. (1995). Notes on Early Bronze Age Urbanization and Urbanism. Tel Aviv, 
22, 47-69. https://doi.org/10.1179/tav.1995.1995.1.47

Finkelstein, I., \& Gophna, R. (1993). Settlement, Demographic and Economic Patterns in the Highlands of Palestine in the Chalcolithic and Early Bronze Periods and the Beginning of Urbanism. Bulletin of the American Schools of Oriental Research, 289, 1-22. https://doi.org/10.2307/1357359

Franken, H. J. (1969). Excavations at Tell Deir'Alla. Leiden Brill.

Gardiner, A. H. (1947). Ancient Egyptian Onomastica (Vol. 1). Oxford: Oxford University Press.

Joffe, A. H., \& Dessel, J. P. (1995). Redefining Chronology and Terminology for the Chalcolithic of the Southern Levant. Current Anthropology, 36, 507-518. https://doi.org/10.1086/204388

Levy, T. (1995). Cult, Metallurgy and Rank Societies-Chalcolithic Period (ca. 4500-3500 BCE). In T. Levy (Ed.), The Archaeology of Society in the Holy Land (pp. 226-244). London: Cassell.

Needham, J. (1958). The Development of Iron and Steel Metallurgy in China. Cambridge: Cambridge University Press.

Netting, R. (1990). Population, Permanent Agriculture, and Polities: Unpacking the Evolutionary Portmanteau. In S. Upham (Ed.), The Evolution of Political Systems: Sociopolitics in Small-Scale Sedentary Societies (pp. 21-61). Cambridge: Cambridge University Press.

Peltenburg, E. (1987). Early Faience: Recent Studies. Origin and Relations with Glass. In M. Binson, \& I. Freestone (Eds.), Early Vitreous Materials (pp. 5-29). London: British Museum.

Peltenburg, E. J. (1995). Tell Banat-Tomb I. Damaszener Mitteilungen, 8, 1-50.

Philips, G. (2001). The Early Bronze I-III Ages. In B. MacDonald, R. Adams, \& P. Bienkowski (Eds.), The Archaeology of Jordan (pp. 163-232). Sheffield: Sheffield Academic Press.

Potter, D. R., \& King, E. M. (1995). A Heterarchical Approach to Lowland Maya Socioeconomics. In R. M. Ehrenreich, C. L. Crumley, \& J. E. Levy (Eds.), Heterarchy and the Analysis of Complex Societies (pp. 17-32). Arlington, MA: American Anthropological Association. https://doi.org/10.1525/ap3a.1995.6.1.17

Pritchard, J. B. (1968). New Evidence on the Role of the Sea Peoples in Canaan at the Beginning of the Iron Age. In The Role of the Phoenicians in the Interaction of Mediterranean Civilizations (pp. 99-112). Beirut: American University of Beirut.

Pritchard, J. B. (1980). The Cemetery at Tell es-Sa'idiyeh, Jordan. Philadelphia, PA: University of Pennsylvania Museum of Archaeology and Anthropology.

Pritchard, J. B. (1985). Tell es-Sa'idiyeh: Excavations on the Tell, 1964-1966. Pennsylvania.

Schwartz, G. M., \& Falconer, S. E. (1994). Rural Approaches to Social Complexity. In G. M. Schwartz, \& S. E. Falconer (Eds.), Archaeological Views from the Countryside: Village Communities in Early Complex Societies (pp. 1-9). Washington, DC: Smithsonian Institution Press.

Stein, G. (1998). Heterogeneity, Power and Political Economy: Some Current Research Issues in Archaeology of the Old World Complex Societies. Journal of Anthropological Research, 6, 1-44. https://doi.org/10.1007/BF02443149

Stein, G., \& Blackman, M. J. (1993). The Organizational Context of Specialized Craft Production in Early Mesopotamian States. Research in Economic Anthropology, 14, 29-59. 
Tubb, J. N. (1988a). Tell es-Sa'idiyeh: Preliminary Report on the First Three Seasons of Renewed Excavations. Levant, 20, 23-88. https://doi.org/10.1179/lev.1988.20.1.23

Tubb, J. N. (1988b). The Role of the Sea Peoples in the Bronze Industry of Palestine/Transjordan in the Late Bronze-Early Iron Transition. In J. Curtis (Ed.), Bronze Working Centres of Western Asia (pp. 251-270). London: Kegan Paul.

Tubb, J. N. (1990). Preliminary Report on the Fourth Season of Excavations at Tell es-Sa'idiyeh in the Jordan Valley. Levant, 22, 21-42. https://doi.org/10.1179/lev.1990.22.1.21

Tubb, J. N., \& Dorrell, P. G. (1991). Tell es-Saidiyeh: Interim Report on the Fifth (1990) Season of Excavations. Levant, 23, 67-86. https://doi.org/10.1179/lev.1991.23.1.67

Tubb, J. N., \& Dorrell, P. G. (1993). Tell es-Saidiyeh: Interim Report on the Sixth Season of Excavations. Palestine Exploration Quarterly, 125, 50-74. https://doi.org/10.1179/peq.1993.125.1.50

Tubb, J. N., \& Dorrell, P. G. (1994). Tell es-Saidiyeh 1993: Interim Report on the Seventh Season of Excavations. Palestine Exploration Quarterly, 126, 52-67. https://doi.org/10.1179/peq.1994.126.1.52

Tubb, J. N., Dorrell, P. G., \& Cobbing, F. J. (1996). Interim Report on the Eighth (1995) Season of Excavations at Tell es-Saidiyeh. Palestine Exploration Quarterly, 128, 16-40. https://doi.org/10.1179/peq.1996.128.1.16

Tubb, J. N., Dorrell, P. G., \& Cobbing, F. J. (1997). Interim Report on the Ninth Season (1996) of Excavations at Tell es-Saidiyeh, Jordan. Palestine Exploration Quarterly, 129, 54-77. https://doi.org/10.1179/peq.1997.129.1.54

Tubb, J., \& Chapman, R. L. (1990). Archaeology and the Bible. London: British Museum Publications.

Tylecote, R. F. (1992). A History of Metallurgy. London: The Metals Society.

van der Steen, E. J. (2001). Excavations at Tell el-Hammeh. Studies in the History and Archaeology of Jordan, 7, 229-232.

van der Steen, E. J. (2003). Tribes and Territories in Transition: The Central East Jordan Volley and Surrounding Regions in the Late Bronze and Early Iron Ages: A Study of the Sources. Groningen: Rijksuniversiteit Groningen.

van der Steen, R. J. (1997). Excavations at Tell el-Hammeh. Occident and Orient, 3, 12-14.

Veldhuijzen, H. A. (1998). Early Iron Smelting. Analysis and Interpretation of Late Iron Age Iron Smelting Remains from Tell Hammehaz-Zarqa, Jordan. Unpublished M.A. Thesis, Leiden: Leiden University.

Veldhuijzen, H. A. (2000). Early Iron Production Found in the Jordan Valley. Orient Express (février), 9-12.

Veldhuijzen, H. A., \& van der Steen, E. J. (2000). Early Iron Smelting (Tell-Hammeh, Jordan). Archaeology, 53, 21.

Veldhuijzen, X., \& van der Steen, E. J. (1999). Iron Production Center Found in the Jordan Valley. Near Eastern Archaeology, 62, 195-199. https://doi.org/10.2307/3210714

Wattenmaker, P. (1994). State Formation and the Organization of Domestic Craft Production at Third Millennium BC Kurban Höyük, Southeast Turkey. In G. M. Schwartz, \& S. E. Falconer (Eds.), Archaeological Views from the Countryside: Village Communities in Early Complex Societies (pp. 109-120). Washington, DC: Smithsonian Institution Press. 